\title{
Electrophoretic analysis, labeling and isolation of Chlamydomonas reinhardtii flagellum membrane proteins
}

\author{
ALFKSANDER F. SIKORSKI
}

Institute of Biochemistry, University of Wrocław, ul. Tamka 2, 50-137 Wrockaw, Poland

(Received: May 30, 1979)

\section{Abstraot}

\begin{abstract}
SDS-polyacrylamide electrophoretic patterns of Chlamydomonas flagellum membrane proteins displayed 6 fractions, 3 PAS-positive among them. The surface radiolabeling of the flagellum membrane suggested an outer surface exposure of fraction ' 5 ', and internal localization of fractions ' 4 ' and ' 6 '. Application of SDS-polyacrylamide gel electrophoresis and radiolabeled membranes allowed to isolate individual membrane polypeptides.
\end{abstract}

\section{INTRODUCTION}

The biflagellate, single-celled alga Chlamydomonas reinhardtii, is known to have several adventages for the study of cell differentiation (J o n e s, 1970; Sik orski, 1978). The flagellum membrane is covered with thin hairlike structures called mastigoneme ( $\mathrm{R}$ in g o, 1967), which were found to be composed of a single high molecular weight glycoprotein (W i t m a n et al., 1972). According to W it ma n et al. (1972) and Snell (1976), purified flagellum membranes give in SDS-polyacrylamide gel electrophoresis one major and one or two minor protein bands. The major band is also a glycoprotein. In this report methods for isolation as well as some properties of Chlamydomonas renhardtii flagellum membranes such as: SDS-polyacrylamide gel electrophoretic analysis, surface labeling of membrane polypeptides and isolation of individual polypeptide fractions are described.

\section{MATERIALS AND METHODS}

Chlamydomonas strain 89 was used. Cultures were carried out according to $\mathrm{Kates}$ and Jones (1964). Cultures were stirred and bubbled with $5 \% \mathrm{CO}_{2}$ in air. Cells were grown for 7-8 days to the 
density of $2-4 \times 10^{6}$ cells per $\mathrm{ml}$ in automatically controlled temperature $\left(25^{\circ}\right)$, synchronized on a 12-hours light, 12 hours dark cycle, and were harvested after four hours in light by continuous flow centrifugation at $20^{\circ} \mathrm{C}$ at 7000 r.p.m. (RC-2B Sorvall, SS-34 rotor). The cells remained intact and flagellated.

Flagella and flagellum membranes were isolated according to W it m a n et al. (1972) with small modifications: concentration of $\mathrm{CaCl}_{2}$ added after STEEP $(0.15 \mathrm{M}$ sucrose; $15 \mathrm{mM}$ Tris; $2.5 \mathrm{mM}$ disodium EDTA; $11 \%$ ethanol; $30 \mathrm{mM} \mathrm{KCL)} \mathrm{treatment} \mathrm{of} \mathrm{cell} \mathrm{suspension} \mathrm{was}$ raised to $30 \mathrm{mM}$. Flagella were purified by additional centrifugation on $40 \%$ sucrose. In membrane isolation the dialysis period was extended to 48 hours and differential centrifugation was carried out on $45^{\%} \%$ sucrose.

Cells were stirred with one volume of cold $10 \mathrm{mM}$ Tris-HCL buffer pH 7.8 and 5 volumes of cold STEEP solution for 2 minutes, then $\mathrm{CaCl}_{2}$ solution was added to the final concentration of $30 \mathrm{mM}$. Cell suspension $(15 \mathrm{ml})$ was overlayered on $25 \mathrm{ml}$ of $25 \%$ sucrose in $10 \mathrm{mM}$ Tris- $\mathrm{HCl}$, $\mathrm{pH} 7.8$, and centrifuged at $2000 \times \mathrm{g}$ for $10 \mathrm{~min}$. The upper and middle layers containing flagella were aspirated and centrifuged for $20 \mathrm{~min}$. at $31000 \times \mathrm{g}$. The flagellum pellet was suspended in $10 \mathrm{mM}$ Tris- $\mathrm{HCl}, \mathrm{pH}$ 7.8 , overlayered on $40 \%$ sucrose in $10 \mathrm{mM}$ Tris- $\mathrm{HCl}, \mathrm{pH} 7.8$, and centrifuged at $3000 \times \mathrm{g}$. for $10 \mathrm{~min}$. The flagella were collected from the upper and middle layers by centrifugation at $31000 \times \mathrm{g}$.

Isolated flagella, after extensive washing with Tris- $\mathrm{HCl}, \mathrm{pH}$ 7.8, were suspended in a solution containing $0.1 \mathrm{mM}$ EDTA; $0.01 \% 2$ -mercaptoethanol; $1 \mathrm{mM}$ Tris, $\mathrm{pH} 8.0$ and dialysed for 48 hours against the same buffer. The suspension was then overlayered on $45 \%$ sucrose in $10 \mathrm{mM}$ Tris- $\mathrm{HCl}, \mathrm{pH} 7.8$, and centrifuged for $90 \mathrm{~min}$. at $16000 \times \mathrm{g}$. Membranes remained in the upper layer, axonemes sedimented completely, and between was the layer of membranes not completely detached from the tubular material (interface, see Table 1). The membrane layer was collected and centrifuged at $105000 \times \mathrm{g}$. for 2 hours (supernatant and membrane pellet, see Table 1). Preparations for electron microscopy were negatively stained with phosphotungstic acid.

Polyacrylamide gel electrophoresis was carried out in the presence of $0.1 \%$ sodium dodecyl sulphate (SDS) according to $\mathrm{F} \mathrm{a} \mathrm{i} \mathrm{rbanks}$ et al. (1971). Electrophoresis was run in glass tubes $0.5 \times 10 \mathrm{~cm}$ at $2 \mathrm{~mA}$ per tube for $15 \mathrm{~min}$. and then at $4 \mathrm{~mA}$ per tube for 4 hours. Gels were stained with $0.25 \%$ Coomassie brilliant blue R-250 in $40 \%$ methanol in $10 \%$ acetic acid and destained with $40 \%$ methanol in $10 \%$ acetic acid for 6 hours, followed by 10 per cent acetic acid. Periodic acid Shiff staining procedure (PAS) was carried out according to $\mathrm{Fa}$ i $\mathrm{rbanks}$ et 
al. (1971) including gel fixation. Material which was to be subjected to electrophoresis was solubilized (to the mentioned final concentrations) in $1 \%$ SDS; $8 \%$ sucrose; $10 \mathrm{mM}$ tris HCL pH $8.0 ; 1 \mathrm{mM}$ EDTA; 40 mi DTT and $10 \mu \mathrm{g} / \mathrm{ml}$ of pyronin Y for $5 \mathrm{~min}$. in a boiling water bath. Stained gels were scanned at $625 \mathrm{~nm}$ and $550 \mathrm{~nm}$ with a Gilford linear transport (2410 S) unit equipped with a Gilford (2000) recorder and Beckman monochromator.

Routine SDS-polyacrylamide gel electrophoresis was used to isolate polypeptide fractions of flagellum membrane. On each gel a sample of membrane suspension labeled with ${ }^{125} \mathrm{I}$ related to $200 \mu \mathrm{g}$ of membrane protein was applied. After electrophoresis the gels were removed from the tubes, cut into $1 \mathrm{~mm}$ slices and the radioactivity of each was measured. Gel slices corresponding to appropriate protein fractions were pooled and extracted with $0.1 \% \mathrm{SDS}$ in $0.04 \mathrm{M}$ Tris; $0.02 \mathrm{M}$ sodium acetate; acetic acid to $\mathrm{pH} 7.4(0.2 \mathrm{ml}$ for each slice) twice for 24 hours with continuous shaking. Extracts were dialysed twice against 50\% (v/v) methanol, three times against water and lyophilised.

The membrane and flagella iodination procedure was taken from B o x e r et al. (1974). To the suspension of flagella (5 mg protein per $\mathrm{ml}$ ) and flagellum membranes $(5 \mathrm{mg} / \mathrm{ml})$ in isoosmotic sodium phosphate buffer $\left(0.155 \mathrm{M} \mathrm{NaH}_{2} \mathrm{PO}_{4}\right.$ adjusted to $\mathrm{pH} 7.4$ with $\left.0.103 \mathrm{M} \mathrm{Na}_{2} \mathrm{HPO}_{4}\right)$ $\mathrm{Na}^{125} \mathrm{I}$, apprx. $2.5 \times 10^{8}$ c.p.m. and $0.1 \mathrm{mg}$ of lactoperoxidase per milligram of protein were added. The reaction was run at room temperature. $\mathrm{H}_{2} \mathrm{O}_{2}$ (total $600 \mathrm{nM}$ ) was added in $10 \mu \mathrm{l}$ aliquots at $3 \mathrm{~min}$. intervals, within one hour. After iodination the flagella were washed twice with isoosmotic buffer and once with $10 \mathrm{mM}$ Tris- $\mathrm{HCl}, \mathrm{pH} 7.8$, followed by the isolation of membranes. Labeled membranes as well as those isolated from labeled flagella, were washed with $10 \mathrm{mM}$ Tris- $\mathrm{HCl}, \mathrm{pH}$ 7.8. Labeled material was subjected to electrophoresis (about $100 \mu \mathrm{g}$ on each gel) and stained with Coomassie blue in standard conditions. Afterwards the gels were scanned, frozen in solid $\mathrm{CO}_{2}$ and cut in to $1 \mathrm{~mm}$ slices with a Joyce Loebl Gel Slicer (The Mickle Laboratory Engineering Co. USA). Radioactivity measurements were carried out with the use of the Isodyne 1185 Automatic Gamma System (Nuclear Chicago).

Protein determinations were carried out according to the $\mathrm{Hart} \mathrm{r} \in \mathrm{e}$ (1972) modificaltion of Low ry et al. (1951) method. Bovine serum albumin was used as a standard. Carbohydrate content analyses were performed by the phenol method of $\mathrm{Dub}$ is et al. (1951) and total phosphorus by the method of Bartlett (1958). Phospholipid content was estimated by multiplying total phosphorus content by 25 .

Chemicals: Acrylamide, $\mathrm{N}, \mathrm{N}^{\prime}$-methylene-bis-acrylamide and TEMED $\left(\mathrm{N}, \mathrm{N}, \mathrm{N}^{\prime}, \mathrm{N}^{\prime}\right.$-tetramethylenediamine) were purchased from BioRad. Lactoperoxidase (40-50 units per milligram) and Tris (hydroxymethyl)-amino- 
methane were from Sigma. $\mathrm{Na}^{125} \mathrm{I}(566 \mathrm{mCi}$ per $\mathrm{ml}$ ) was obtained from New England Nuclear. The other chemicals were from Fisher or Mallinckrodt and were of analytical grade.

\section{RESULTS AND DISCUSSION}

An increase of $\mathrm{CaCl}_{2}$ concentration up to $30 \mathrm{mM}$ allowed to avoid flagellum membrane distorsion during the isolation, which was observed when $15 \mathrm{mM} \mathrm{CaCl}_{2}$ was used (Photos 1 and 2).

The amount of isolated flagella estimated as protein was about $0.6 \mathrm{mg}$ per liter of culture.

It was found in electron microscope observations that a 16 hours dialysis period was to short (at least for strain 89) - the membranes were not completely detached from the axonemes. Axonemes, even from flagella isolated in the presence of $15 \mathrm{mM} \mathrm{CaCl}_{2}$ and washed extensively, contained PAS-positive components which were not observed in those obtained after 48 hours dialysis.

Extension of the dialysis period provided complete detachment of membranes. Both membrane preparations contained no tubular structures, and showed no differences in electron microscope examination (Photo 3), as well as in SDS-polyacrylamide gel electrophoresis.

In Table 1 the contribution of flagella fractions obtained by differential centrifugation of flagella dialysates (16 and 48 hours dialysis) is shown. The data presented there show that the yield of membranes obtained through 48 hours dialysis was at least two-fold higher.

\section{Table 1}

Flagellum membranes isolation - total protein content in flagellar fractions obtained by differential centrifugation of dialysed flagellar suspensions

\begin{tabular}{|l|c|c|}
\hline \multicolumn{1}{|c|}{ Fraction } & $\begin{array}{c}\text { Method I } \\
\text { per cent of total } \\
\text { flagellar protein }\end{array}$ & $\begin{array}{c}\text { Method II } \\
\text { per cent of total } \\
\text { flagellar protein }\end{array}$ \\
\hline Dialysed flagella & 100 & 100 \\
\hline Interface & 20.5 & 10.0 \\
Axonemes & 46.9 & 49.2 \\
Supernatant & 23.7 & 19.8 \\
Membrane pellet & 8.9 & 21.0 \\
\hline
\end{tabular}

Flagellar preparations were dialysed 16 (Method I) or 48 (Method II) hours against 0.1 mM EDTA; $0.01 \% 2$-mercaptoethanol in $0.1 \mathrm{mM}$ Tris, $\mathrm{pH} 8.0$. The dialysate was submitted to differential centrifugation on $45 \%$ sucrose in $10 \mathrm{mM}$ Tris- $\mathrm{HCl}$, pH 7.8 for 3 hours at $16000 \times \mathrm{g}$. Three fractions were obtained: membranes 'interface' and axoneme pellet. The fraction containing membranes was centrifuged for two hours at $105000 \times \mathrm{g}$. The data concern strain 89 vegetative flagella. 


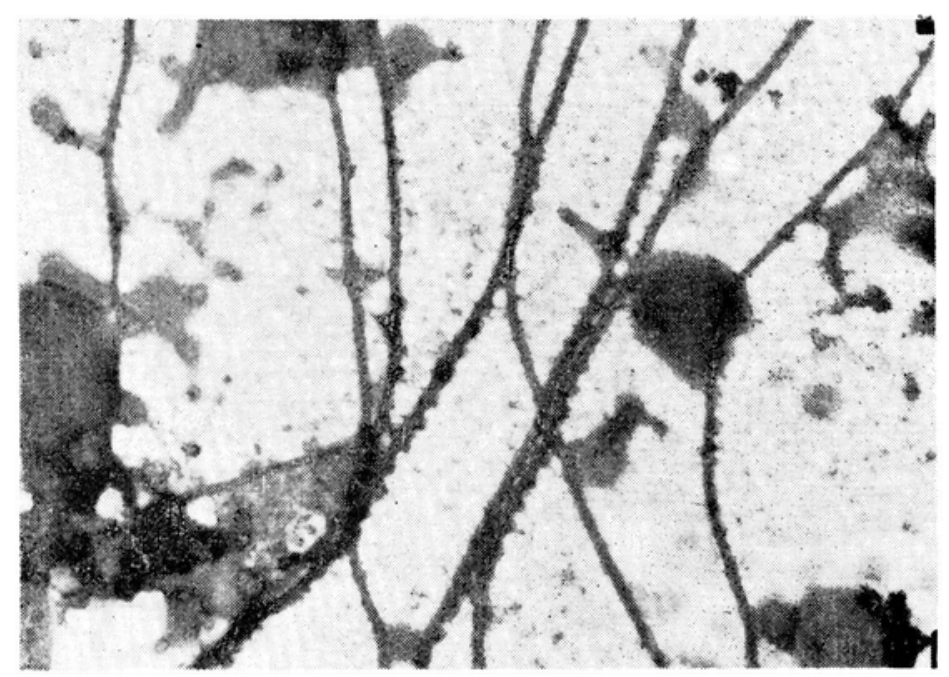

Photo 1. Chlamydomonas flagella isolated according to Witman et al. (1972); $\times 15000$, negative staining.

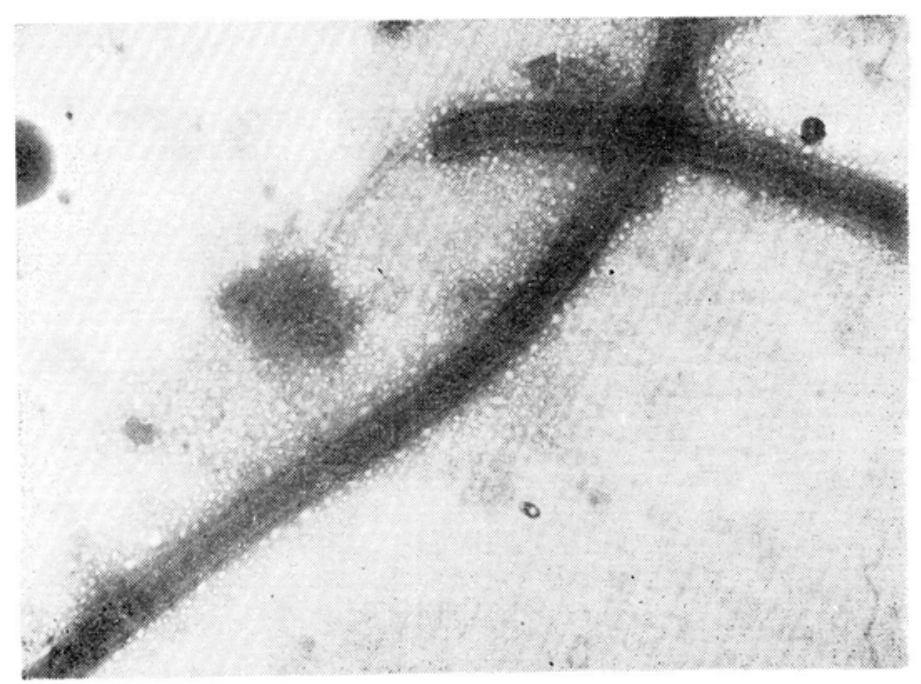

Photo 2. Chlamydomonas flagella isolated in the presence of $0.03 \mathrm{M} \mathrm{CaCl}{ }_{2}$; $\times 40000$, negative staining. 


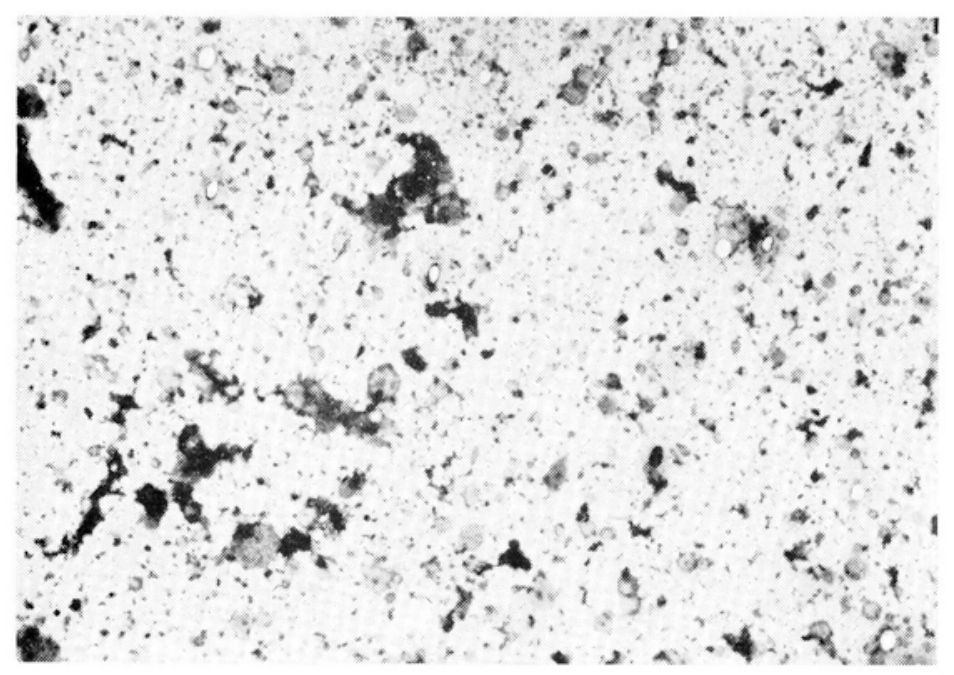

Photo 3. Chlamydomonas flagellum membranes isolated after 48 hours dialysis; $\times 25000$, negative staining. 
Purified membranes were found to contain $54.1 \%$ of protein, $33.8 \%$ of carbohydrates and $12.1 \%$ of phospholipids.

Electrophoretic patterns of total flagella proteins obtained in the presence of $0.1 \%$ SDS in $5.6 \%$ polyacrylamide gel displayed ten and in $7.0 \%$ gel twelve polypeptide bands (Fig. 1). In both gel concentrations

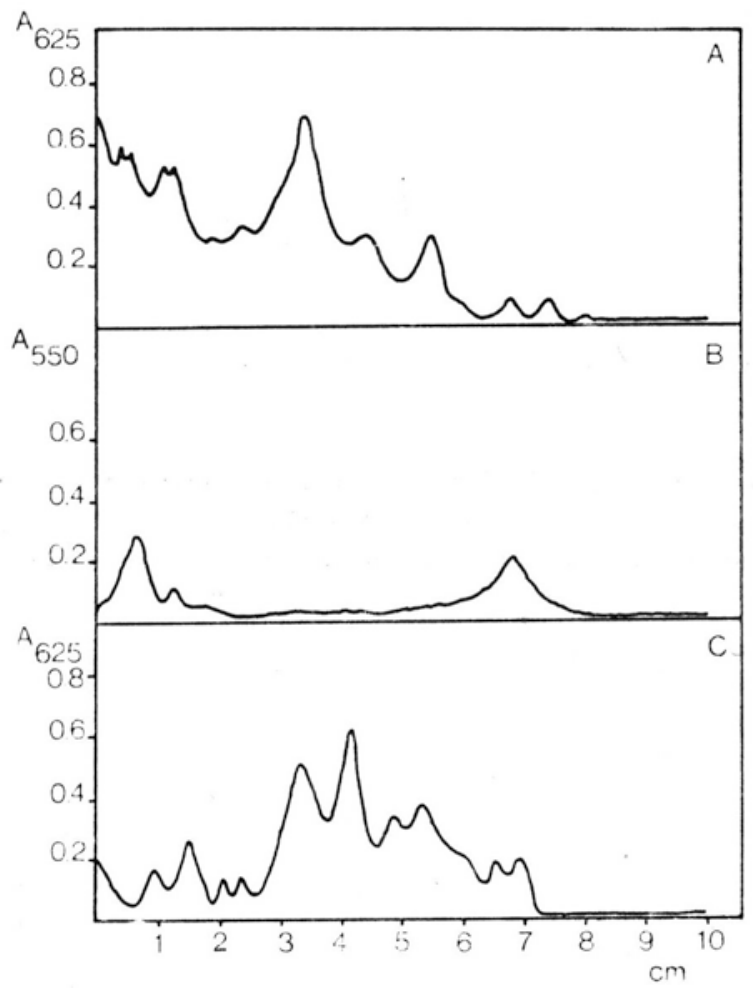

Fig. 1. Polyacrylamide gel electrophoresis of total flagellum proteins of vegetative cells, strain 89 in the presence of $0.1 \%$ SDS.

a - gel $7.0 \%$, Coomassie blue staining, $100 \mu \mathrm{g}$ of protein; b - gel $7.0 \%$, PAIS-staining, $100 \mu \mathrm{g}$ of protein; c - gel $5.6 \%$, Coomassie blue staining, $100 \mu \mathrm{g}$ of protein.

three PAS-positve components were found. The axoneme fraction in $7.0 \%$ gel electrophoresis displayed two main tubulin bands and one minor of high molecular weight — probably aggregated tubulin, and in $5.6 \%$ gel only one major band (Fig. 2).

Electrophoretic patterns of flagellum membrane proteins obtained in $5.6 \%$ gel (Fig. 3) displayed six protein bands, including three PAS-positive components. The PAS-positive fraction '2' stained with Coomassie blue very weakly or was not stained at all.

Freshly prepared flagella were used to label proteins accessible from the external surface of the membrane, and membrane preparations to label both their sides. Both membrane preparations were subjected to 


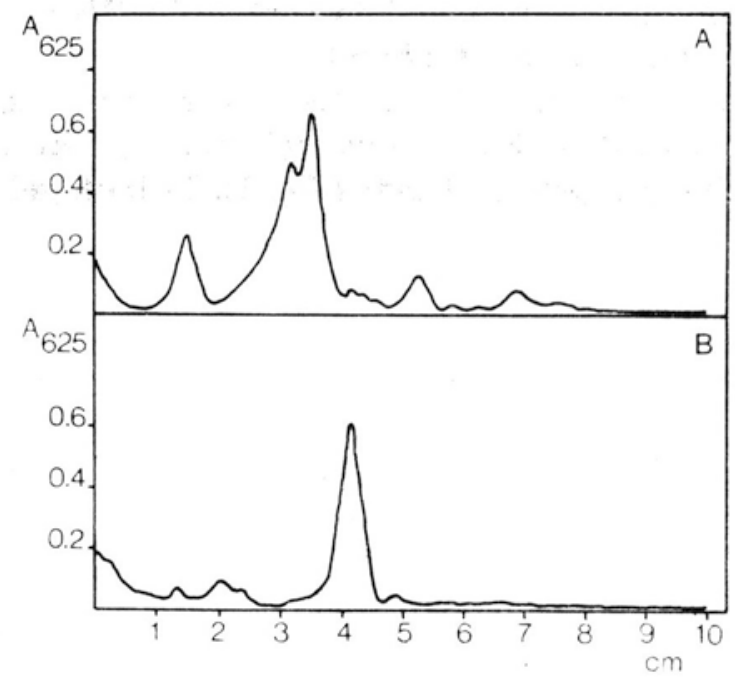

Fig. 2. SDS-polyacrylamide gel electrophoresis of strain 89 vegetative flagellum axoneme proteins.

a - gel $7.0 \%$, Coomassie blue staining, $100 \mu \mathrm{g}$ of protein; b-gel $5.6 \%$, Coomassie blue staining, $100 \mu \mathrm{g}$ of protein.

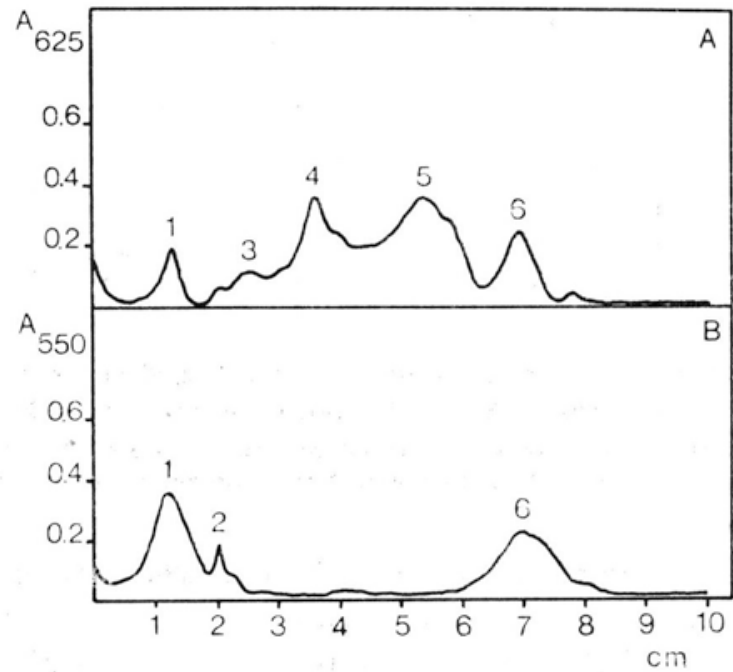

Fig. 3. SDS-polyacrylamide gel $\left(5.6^{0} \%\right)$ electrophoresis of strain 89 vegetative flagellum membrane proteins.

a - Coomassie blue staining, $100 \mu \mathrm{g}$ of protein; b - PAS staining, $50 \mu \mathrm{g}$ of protein.

electrophoresis in standard conditions (Fig. 4). Results of a similar experiment where the axoneme fraction of labeled flagella was used to test the impermeability of membranes to lactoperoxidase are shown in Fig. 4c. 


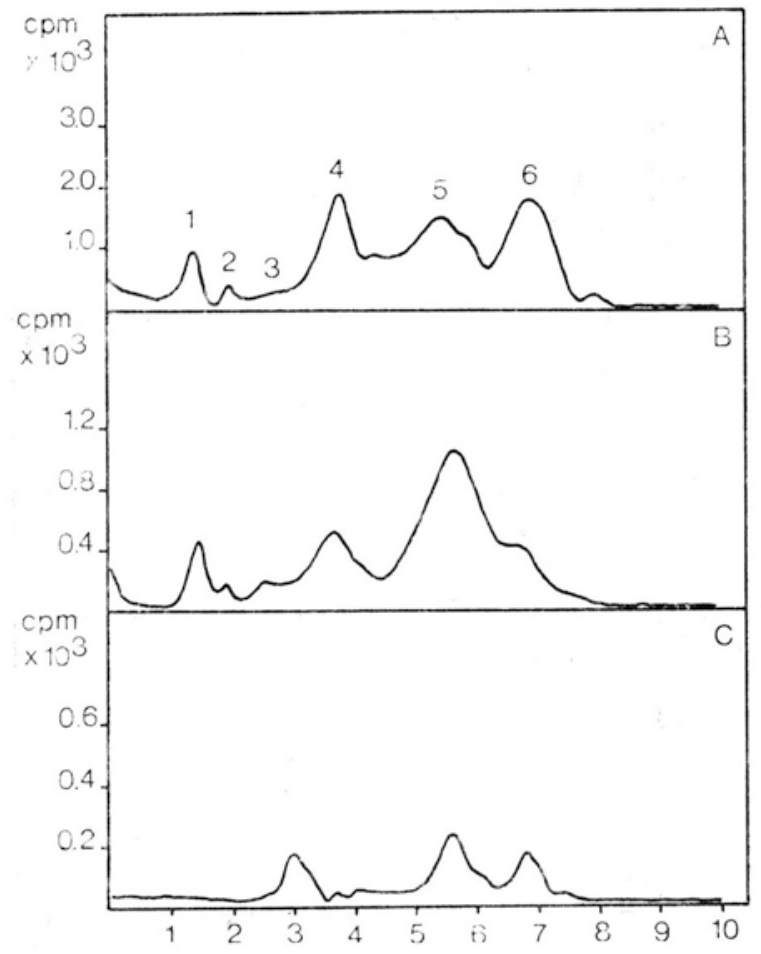

Fig. 4. SDS-polyacrylamide gel electrophoresis of strain 89 vegetative flagelium membranes labeled with ${ }^{125} \mathrm{I}$. Radioactivity profiles.

a - isolated membrane preparation labeled, $100 \mu \mathrm{g}$ of protein, $1.3 \times 10^{5}$ c.p.m.; b - membranes obtained from labeled flagella, $100 \mu \mathrm{g}$ of protein, $2.5 \times 10^{4}$ c.p.m.; c - axoneme fraction obtained from labeled flagella, $100 \mu \mathrm{g}$ of protein.

In the lactoperoxidase system almost all the flagellum membrane polypeptide fractions (with the exception of fraction ' 3 ' which is always distincly stained with Coomassie blue) can be labeled with ${ }^{125}$ I. Fraction '2' which stains for protein very weakly shows a significant peak in radioactive profile at the position of glycoprotein '2'.

Comparison of radioactive profiles of membrane proteins labeled after membrane isolation and obtained from labeled flagella indicates the differences connected mainly with the amount of label in fractions ' 4 ', ' 5 ' and '6'. Fractions ' 4 ' and ' 6 ' bear relatively less label in the case of intact labeled flagella, what can suggest their localization at the internal axonemal surface. Polypeptide(s) ' 5 ' is labeled in this case more intensely, so an external, easily accessible to lactoperoxidase, localization is suggested.

The radioactive profiles obtained after electrophoresis of labeled membranes were similar to the stained and fixed ones (Fig. 4a). After extraction of pooled gel slices containing appropriate membrane poly peptide fractions $50-70^{\%} \%$ of radioactivity was recovered in the extracts. 
A. F. Sikorski
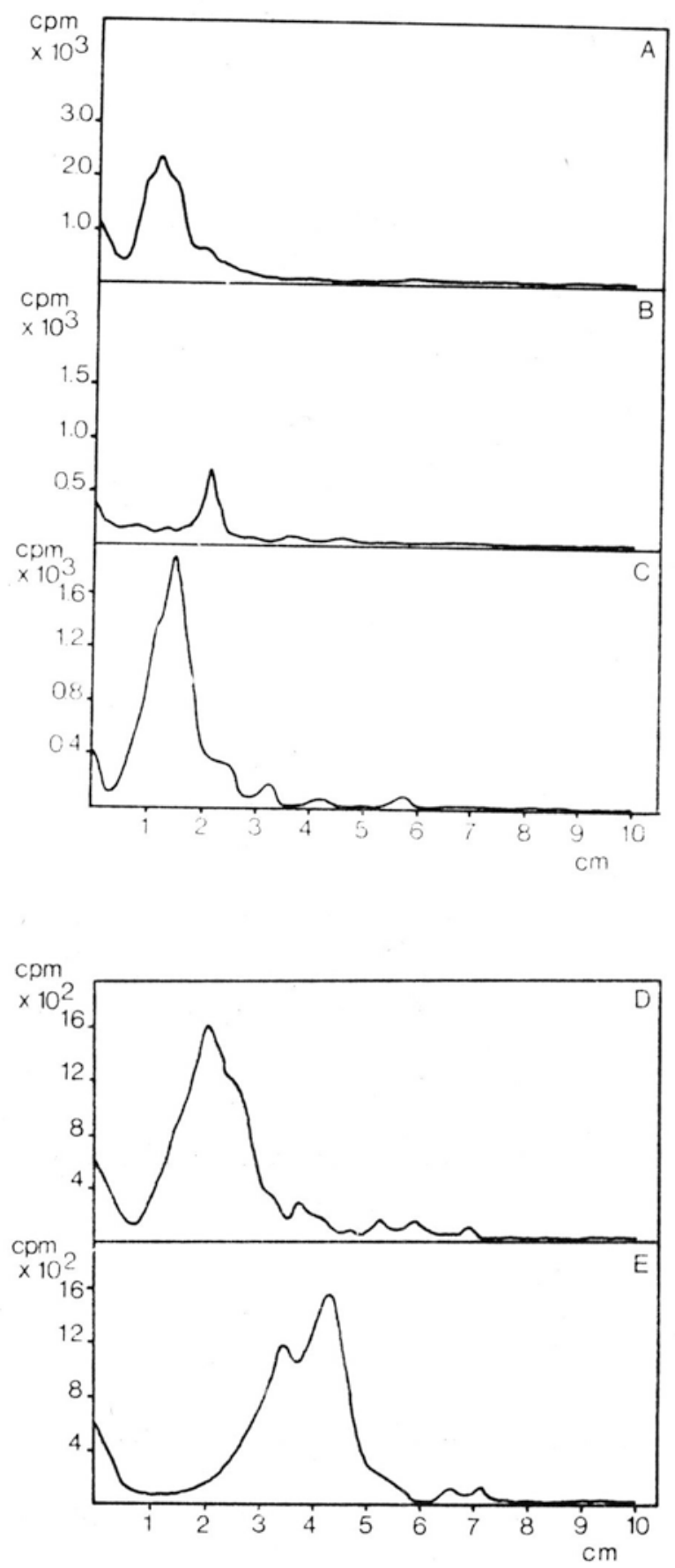

Fig. 5. SDS-polyacrylamide gel electrophoresis of isolated protein fractions of strain 89 vegetative flagellum membranes. Radioactivity profiles.

a and b - gel 5.6\%, fractions no. 1 , and no. 2 respectively; c, d, e - gel $7.5 \%$, fractions no. 3,4 and 5 respectively. 
Fixed and stained with Coomassie blue gels yielded only $30-50 \%$ of radioactivity.

The radioactive tracing patterns obtained after re-electrophoresis of isolated fractions ' 1 ' and ' 2 ' in $5.6 \%$ gel and of fractions ' 3 ', ' 4 ', ' 5 ' in $7.5 \%$ gel are presented in Fig. 5. It can be seen from the presented data that isolated fractions are only slightly contaminated reciprocally and all, with the exception of fraction '5', display single peaks. Fraction '5' shows two well separated peaks.

Although the purity of the isolated membrane preparations has been well documented, the electrophoretic results differ from similar reports on flagellum membranes - W i t $\mathrm{m}$ a $\mathrm{n}$ et al. (1972), B e r g m a $\mathrm{n}$ et al. (1975), Snell (1976). Fractions '1' and '2' are the same in all cited reports, but the number of other fractions is different among them. The results of S n ell (1976), who observed in the 'gamone' preparation 6-7 protein fractions seem to be in good agreement with those obtained here. Apart from one report on Paramecium cilia ( $\mathrm{H} \mathrm{ansm}$ a and $\mathrm{Kung}, 1975)$, that small number of polypeptides in biological membranes is rather rare, e.g. $\mathrm{Stubbaiah}$ and $\mathrm{Thompson}$ (1974) observed at least 4 protein bands in the Tetrahymena ciliary membrane, and $\mathrm{Chua}$ and Bennoun (1975) as many as 33 polypeptide chains in Chlamydomonas thylacoid membranes. In the most extensively studied erythrocyte membranes there are at least 20 polypeptide fractions ( $\mathrm{J} \mathrm{uli}$ a $\mathrm{no}$, 1973). The differences in the number of electrophoretic fractions might be due to the different solubilization methods, the amount of material applied, and staining procedures. The lactoperoxidase system used for labeling flagellum proteins is an attempt to determine their exposure to the external flagellar surface. The results presented here suggest that polypeptides of fraction '5' or one of them are exposed to this surface. It should be noted, that tubulin in leaky flagella and in isolated axonemes was easily labeled with ${ }^{125} \mathrm{I}$. An unexpected result is the unchanged radioactivity pattern of fraction '2' - which is supposed to be the main mastigoneme component. Probably its high carbohydrate content interferes with radiolabeling in native flagella. To sum up, the obtained results are in good agreement with the generally accepted model of membrane protein organization (S inger and $\mathrm{Nicolson}, 1972$ ). It should be noted that no extrinsic proteins in the flagellum membrane have been observed so far. Despite attempts, membrane preparations containing more protein fractions (shorter dialysis periods) and/or less (dialysis of membrane preparations against $0.02 \mathrm{M}$ EDTA $\mathrm{pH}$ 8.5) were not obtained. 
Acknowledgments

The author wishes to thank dr R. F. J ones for help and guidance during his stay at Stony Brook.

The author is greatly indebted to professor W. Mejbaum-Katzenellen bogen for advice and a valuable discussion during manuscript preparation.

This study was supported in part by an INT Grant No. 76/22205.

\section{REFERENCES}

B a rtlett G. R., 1958. Phosphorus assay in column chromatography. J. Biol. Chem. 234: 466-468.

Bergman K., Goodenough U. W., Goodenough D. A., Jawitz J., Martin H., 1975. Gametic differentiation in Chlamydomonas reinhardtii II. Flagellar membranes and the agglutination. J. Cell. Biol. 67: 606-622.

B oxer D. H., Jenkins R. E., T anner M. J. A., 1974. The organization of the major protein of the human erythrocyte membrane. Biochem. J. 137: 531-534.

Chu a N-H., Bennoun B., 1975. Thylakoid membrane polypeptides of Chlamydomonas reinhardtii. Wild-type and mutant strains deficient in photosystein II reaction center. Proc. Natl. Acad. Sci. USA, 72: 2175-2179.

Dubois M., Gilles K. A., Hamilton J. K., Roberts P. A., Smith F., 1956. Colorimetric determination of sugars and related substances. Anal. Chem. 28: $350-356$.

Fairbanks G., Steck T. L., Wa 11 a ch D. F. H., 1971. Electrophoretic analysis of the major polypeptides of the human erythrocyte membrane. Biochemistry 10: 2606-2617,

H ansma H. G., K ung C., 1975. Studies of cell surface of Paramecium. Ciliary membrane proteins and immobilization antigens. Biochem. J. 152: 523-528.

Hartree E. F., 1972. Determination of protein: A modification of the Lowry method that gives a linear photometric response. Anal. Biochem. 48: 422-427.

Jones R. F., 1970. Physiological aspects of growth and gametogenesis in Chlamydomonas reinhardtii. Ann. N. Y. Acad. Sci. 175: 648-659.

J uli a no R. L., 1973. The proteins of the erythrocyte membrane. Blochim. Biophys. Acta 300: 341-378.

Kates J. R., J ones R. F., 1964. The control of gametic differentiation in liquid cultures of Chlamydomonas. J. Cell Comp. Physiol. 63: 157-164.

Lowry O. H., Rosenbrough A. I., Farr A. L., Randal1 R. J., 1951. Protein measurement with the Folin phenol reagent. J. Biol. Chem. 193: 265-275.

R ing o D. L., 1967. Flagellar motion and fine structure of the flagellar apparatus in Chlamydomonas. J. Cell Biol. 33: 548-571.

Sikorski A. F., 1978. Chlamydomonas reinhardtii and its flagella as model for the study of molecular basis of differentiation and development of organisms. Post. Biol. Komórki 5: 261-277.

Sing er S. J., Nicols on G. L., 1972. The fluid masaic model of the structure of cell membranes. Science 175: 720-721.

Sne 11 W. J., 1976. Mating in Chlamydomonas: A system for the study of specific cell adhesion. I. Ultrastructural and electrophoretic analysis of flagellar surface components involved in adhesion. J. Cell Biol. 68: 48-69. 
Stubbaiah P. V., Thompson G. A., 1974. Studies on membrane formation in Tetrahymenx pyriformis. The biosynthesis of proteins and their assembly into membranes of growing cells. J. Biol. Chem. 249: 1302-1310. Witman G. B., Carlson K., B erliner J., Rosenbaum J. L., 1972. Chlamydomonas flagella. I. Isolation and electrophoretic analysis of microtubules, matrix, membranes and mastigonemes. J. Cell Biol. 54: 507-539.

Elektroforeza, znakowanie i izolacja białek błon wici

Chlamydomonas reinhardtii

\section{Streszczenie}

W elektroforezie w żelu poliakryloamidowym w obecności SDS białka blon wici Chlamydomonas wykazują obecność 6 frakcji, w tym 3 dające pozytywnü reakcję z odczynnikiem Shiffa.

Znakowanie powierzchniowe $J^{125}$ białek wici wskazuje na powierzchniową ekspozyoję frakcji '5', a wewnętrzmą aksonemalną lokalizację frakcji '4' i '6'.

Stasując znakowane $J^{125}$ błony wici wyizolowano poszczególne frakcje białkowe w elektroforezie w żelu poliakryloamidowym. 